\title{
Cacao, copoazu and macambo: Exploring Theobroma diversity in smallholder agroforestry systems of the Peruvian Amazon
}

\author{
Elisabeth Lagneaux • Federico Andreotti (iD - Charlotte M. Neher
}

Received: 2 January 2020/Accepted: 6 March 2021/Published online: 1 April 2021

(C) The Author(s) 2021, corrected publication 2021

\begin{abstract}
Over the past decades, the general trend towards shade reduction and intensification of cacao management has led to biodiversity losses. In the Peruvian Amazon, the regional government is heavily promoting crop conversion to shift from regionally marketed foods towards cacao (Theobroma cacao) and copoazu (Theobroma grandiflorum). While this shift is already visibly impacting the farming landscape and the lives of many smallholder farmers, little is known about the reasons that drive farmers to choose certain types of Theobroma species or cacao varieties over others. In this paper, we addressed how cacao farmers perceive and manage specific and varietal Theobroma diversity. We interviewed cacao farmers $(n=20)$ during a seed-exchange fair and adapted a version of the four-square analysis to explore which Theobromas are currently adopted by farmers and why. The native cacao variety (cacao chuncho) was the one cultivated by most farmers,
\end{abstract}

E. Lagneaux

iES Landau, Institute for Environmental Sciences,

University Koblenz-Landau, Landau, Germany

E. Lagneaux

Plant Production Systems Group, Wageningen University,

Box 430, 6700 AK Wageningen, The Netherlands

F. Andreotti $(\square)$. C. M. Neher

Laboratory of Geo-Information Science and Remote

Sensing, Wageningen University \& Research,

6708 PB Wageningen, The Netherlands

e-mail: federico.andreotti@wur.nl followed by the more industrial clonal varieties. The source of seeds and seedlings for the most cultivated varieties was a mix of donations by public institutions (for clonal varieties) and informal exchange among farmers (mainly for native and criollo varieties, and species i.e. macambo (Theobroma bicolor) and cacauillo (Theobroma speciosum)). The cacao varieties incentivized by public institutions were the least desired for future investment. The motivations for farmers to plant Theobromas was mainly based on the perceived current and potential market, but their desire to invest in a given species or variety was also based on pest resistance, traditional use, farm diversification and taste. Copoazu and $\mathrm{CCN}$ cacao varieties are produced by many households in large areas, while macambo, cacauillo and the cacao varieties TSH and porcelana are produced by few households in small areas. Our study suggests that agroforestry systems that include alternative Theobroma species are multistrata and more diverse than cacao-based systems. It

F. Andreotti

CIRAD, SENS, 34398 Montpellier, France

F. Andreotti

SENS, CIRAD, IRD, Univ Paul Valery Montpellier 3,

Univ Montpellier, Montpellier, France

C. M. Neher

Knowledge, Technology and Innovation Group,

Wageningen University \& Research, Wageningen, The Netherlands 
highlights the risks of agrobiodiversity loss associated with the promotion of industrial cacao varieties, and the importance of seed and seedling access for the development of diverse farming systems. We recommend the expansion of local seed-sharing networks and the extension of public cacao-donation campaigns to neglected and underutilized Theobromas with socio-economic and environmental benefits, in order to make the local farming systems more diverse and resilient.

Keywords Agrobiodiversity - Neglected and underutilized species $\cdot$ Seed-exchange $\cdot$ Seed sourcing strategies $\cdot$ Cacao genetic diversity $\cdot$ Theobromas

\section{Introduction}

Agroforestry systems (AFS) are multifunctional agroecosystems which provide, along with crop production (van Noordwijk et al. 2016, 2020), a large range of regulating and supporting ecosystem services such as regulation of local climate, maintenance of soil fertility, carbon storage, and maintenance of genetic diversity (Mortimer et al. 2017; Ellison et al. 2017; Nelson \& Phillips 2018; Andrieu et al. 2019). Appropriate agroforestry management can enhance forest conservation, genetic diversity, food production and livelihoods (Herrero-Jáuregui et al. 2019). Tree diversity within AFS is essential for the conservation of forest-dependent biodiversity and agricultural production (van Noordwijk et al. 2016; Andreotti et al. 2018). The most studied tropical AFS are coffee-based (e.g. Cerda et al. 2017; Andreotti et al. 2020) and cacaobased production systems (e.g. Clough et al. 2009; Saj et al. 2017; Andreotti et al. 2018). Cacao has traditionally been produced within tropical AFS, with cacao trees offering the advantage to be both shade tolerant and shade producing trees contributing to maintaining soil fertility and creating a beneficial microclimate (Sauvadet al. 2019). However, over the past decades, the general trend towards shade reduction and intensification of cacao management has led to biodiversity losses (Saj et al. 2017). While this is true for modern AFS, traditional and more diversified AFS continue to exist. They show greater levels of shade, more tree strata and higher tree species richness across the landscape than conventional AFS (Deheuvels et al. 2012; Saj et al. 2017; Andreotti et al. 2018).

In the Peruvian department of Madre de Dios, where artisanal-scale gold mining has recently caused record deforestation numbers (Caballero Espejo et al. 2018; Finer and Mamani 2018a, b), the regional government is promoting agriculture as an alternative sustainable and legal land-use. Several public programs are heavily investing in crop conversion to shift from regionally marketed foods towards commodity cash crops, i.e. cacao and copoazu (Theobroma grandiflorum) (e.g. MINAGRI 2019a, b). These policies are already having a visible impact on the farming landscape, since between 2010 and 2017, the surface of cultivated rice and corn have decreased respectively by 94 and $83 \%$, while that of cacao has increased by $99 \%$ (INEI 2018). While some consider it as a regional "cacao boom", not all smallholder farmers feel included in the transition towards cacao-based farming systems, an approach that was managed top-down. Grass-root farmer organizations i.e. the Farmer's Federation of Madre de Dios (FADEMAD), who have already lost political power in the last decades (Rojas 2014) feel ignored by regional governments and international development organizations (pers. comm. with FADEMAD leader, September 20, 2019). In order to develop land-use transition policies which are more inclusive of smallholder farmers, there needs to be an increased understanding of their preferences and of the reasons that lead them to prefer one species over another.

In this study, we will focus on Theobroma species-a genus that comprises cacao and copoazu, two important cash crops, and different cacao varieties. Varieties are a taxonomic rank lower than species, meaning that they describe groups of organisms sharing similar traits but belonging to the same species. In order to gain new insights into the reasons that motivate farmers to adopt certain Theobroma species (TS) and cacao varieties (CV) over others, and thereby to provide the first study on the adoption of Theobroma species and varieties in the Peruvian Amazon, we address the following research questions:

1. Which TS and CV are currently adopted by smallholder farmers in the Peruvian Amazon and why?

2. Why are these TS and CV managed and how are they obtained? 


\section{Materials and methods}

All the data was collected during the 2019 seed fair ("Feria de Semillas 2019") which took place on the 12th of October in Puerto Maldonado. This seedexchange fair is the single biggest yearly gathering of farmers in the region. During this event, farmers from the whole region are invited to bring, sell, buy and exchange seeds from their farms. Most farmers are former or active members of the AAE ("Asociación Agricultura Ecologica"-Association of Organic Farmers) and almost all are non-mechanized smallholders managing a diversity of crops.

To explore the knowledge and management of crop diversity amongst the participating farmers, we used an adapted version of the four-square analysis (4SqA) which consists of both quantitative and qualitative components (Grum et al. 2003). While 4SqA usually relies on a participatory focus-group dynamic, farmers were interviewed individually. We interviewed 20 farmers, both men and women, as representatives of the household, among the participants to the fair. This number was considered representative of the 150 agroforestry farms established in the Tambopata Province (Peña 2018), the largest and by far most populous of the three provinces in Madre de Dios.

During the interviews, farmers were first asked to write down all known TS and CV, including those they do not cultivate. Second, they were asked to locate each of the species and varieties in the 4SqA. The $4 \mathrm{SqA}$ is a two-dimensional plane where one axis represents the number of households who cultivate a crop species or variety, and the other axis the approximate combined surface area over which it is grown. Hereafter, the farmers were asked to answer a set of questions with regard to the species and varieties cultivated on their lands (Box 1). Although we used a structured questionnaire, all comments made by the farmers were taken into account.

Participants were asked for their informed consent, which all farmers provided. They were informed that they were free to participate or to stop the interview whenever wanted and that their right of anonymity would be fully respected. Each 4SqA exercise, together with the interviews, took no longer than thirty minutes.

\footnotetext{
Q1. Which crop species/varieties have a high demand on the market?

Q2. Which varieties have a low demand on the market?

Q3. Which varieties produce a low yield?

Q4. Which varieties produce a high yield?

Q5. Which varieties do you plant in the shadow of other trees?

Q6. Which varieties do you plant in the full sun?

Q7. Which varieties are resistant to pests and diseases?

Q8. Which varieties are resistant to drought?

Q9. Which varieties do you intercrop with other varieties of cacao?

Q10.Does this variety have social or cultural value to you?

Q11. Which varieties do you use for self-consumption?

Q12. Which varieties produce byproducts?

Q13. Which varieties would you like to produce (more of) in the future?
}

Box 1 Questionnaire of the $4 \mathrm{SqA}$ interviews 
To explore the results of the 4SqA, a Principal Component Analysis (PCA) was performed. PCA allowed us to retain patterns, thereby simplifying the complexity of the collected data (Lever et al. 2017). The distance matrix was calculated based on the questions presented in Box 1. Overall patterns of the most used species and varieties and related questions asked during the $4 \mathrm{SqA}$ were analyzed. The PCA explanatory variables were six different $\mathrm{TS}$ and $\mathrm{CV}$, namely: VRAE99, CCN51, CCN95, cacao chuncho, macambo and copoazu; while the illustrative variables were the 13 questions introduced in Box 1. We omitted from the PCA the lesser used CV and TS (two farmers or less), because of the normalization and the few data available for them. The PCA was carried out using R 2.13.0 (R Core Team 2013) with the packages mco (Mersmann 2014) and psych (Revelle 2017).

\section{Results}

The 20 cacao producers that we interviewed were familiar with the common names of their cultivated TS and CV. In total, the farmers mentioned $10 \mathrm{CV}$ (Theobroma cacao), 9 of which were identified as

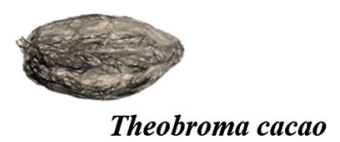

Cacao varieties:

- Cacao Chuncho

- Porcelana

- Cacao Rojo

- CCN51

- CCN95

- TSH

- VRAE15

- VRAE99

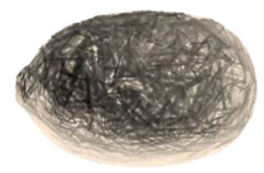

Copoazu

(Theobroma grandiflorum)

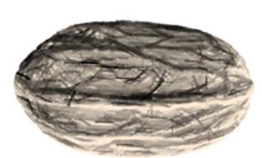

Macambo

(Theobroma bicolor)

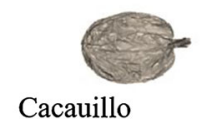

(Theobroma speciosum)
Fig. 1 Representations of the Theobrama species and cacao varieties mentioned by farmers. Each Theobroma species (in bold): cacao (Theobroma cacao), copoazu (Theobroma grandiflorum), macambo (Theobroma bicolor) and cacauillo (Theobroma speciosum) is represented by a sketch of its fruit. Cacao varieties are divided between traditional varieties and hybrids (or clones) different varieties, and 3 other TS: macambo (Theobroma bicolor), copoazu (Theobroma grandiflorum) and cacauillo (Theobroma speciosum) (Fig. 1). The most often mentioned cultivated $\mathrm{CV}$ was cacao chuncho, the native cacao variety (11 farmers).

Farmers obtained the seeds of TS and CV from different organizations, technicians, NGOs and cooperatives, or from other farmers (Table 1). Regarding the $\mathrm{CV}$, the first source of seeds and seedlings was farmer outreach programs, whether through local NGOs or public institutions. For the TS (macambo, cacauillo and copoazú), seeds and seedlings were picked up from the forest or neighboring AFS systems through seed exchange. The CV that farmers wanted to plant more of in the future were VRAE99, VRAE15, CCN51, CCN95, cacao chuncho, and porcelana. The reason that motivated the cultivation of the more intensive $\mathrm{CCN}$ varieties, was related to the confidence farmers have gained in producing the varieties successfully. For porcelana, this reason was related to a better resistance to pests, and for cacao chuncho, it was related to traditional use and delicious taste. Regarding TS, farmers were mainly interested in investing in macambo and copoazu, due to their resistance to pests and the perception that these species have a high market potential. Overall, farmers considered these species a better investment for the future than the CV. Only one farmer mentioned cacauillo for its good business potential.

We combined the $4 \mathrm{SqA}$ interviews within a single figure to represent the overall farmers' perspectives on the cultivation of the different species and varieties (Fig. 2). The 4SqA highlighted the difference in cultivation of the TS and CV, showing which of those are cultivated on large areas and by many households, i.e. copoazu and CCN51; and those cultivated on small areas by few households, i.e. macambo and cacauillo (Fig. 2).

In our PCA, the first and the second axes explained 48.16 and $20.39 \%$ of the total variance for the questions asked during the $4 \mathrm{SqA}$ interviews. From the PCA results (Fig. 3) we could identify two main clusters. The first cluster is composed of copoazu, macambo and CCN51. CCN51 is well represented by the first axis, that is mainly influenced by Q2 (low demand), Q4 (high yield) and Q11 (self-consumption). It is also the one farmers pointed to as most resistant to droughts (Q8). Copoazu and macambo were characterized by farmers as desirable species to be planted 
Table 1 List of Theobroma species (TS) and cacao varieties (CV) mentioned by farmers, along with the source of seeds and seedlings and the reasons mentioned for wanting to cultivate them in the future

\begin{tabular}{|c|c|c|c|c|c|}
\hline \multicolumn{2}{|c|}{ Common name } & \multirow{2}{*}{$\begin{array}{l}\text { Scientific } \\
\text { name }\end{array}$} & \multirow{2}{*}{$\begin{array}{l}\text { Number of } \\
\text { farmers } \\
\text { cultivating it }\end{array}$} & \multirow[t]{2}{*}{ Seed sources } & \multirow{2}{*}{$\begin{array}{l}\text { Reasons mentioned for cultivating the } \\
\text { species/variety in the future }\end{array}$} \\
\hline Species & Variety & & & & \\
\hline \multirow[t]{8}{*}{ Cacao } & $\begin{array}{l}\text { Cacao } \\
\text { Chuncho }\end{array}$ & $\begin{array}{l}\text { Theobroma } \\
\text { cacao }\end{array}$ & 11 & $\begin{array}{l}\text { NGO Caritas, Forest, } \\
\text { neighbor, Seed exchange }\end{array}$ & Traditional, Taste \\
\hline & CCN95 & & 6 & $\begin{array}{l}\text { Technicians, NGO Caritas, } \\
\text { Forest, Cooperative, }\end{array}$ & Confident to produce it successfully \\
\hline & VRAE99 & & 8 & $\begin{array}{l}\text { Technicians, NGO Caritas, } \\
\text { neighbor, Cooperative, }\end{array}$ & Confident to produce it successfully \\
\hline & CCN51 & & 5 & $\begin{array}{l}\text { Technicians, NGO Caritas, } \\
\text { neighbor, GOREMAD }\end{array}$ & High yield \\
\hline & VRAE 15 & & 2 & NGO Caritas & / \\
\hline & $\mathrm{TSH}$ & & 2 & Technicians, GOREMAD & l \\
\hline & Porcelana & & 2 & NGOs, Other farmers & Pest resistant \\
\hline & $\begin{array}{r}\text { Cacao } \\
\text { Rojo }\end{array}$ & & 1 & NGOs & l \\
\hline Macambo & & $\begin{array}{l}\text { Theobroma } \\
\text { bicolor }\end{array}$ & 3 & Forest, Seed exchange & $\begin{array}{l}\text { Pest resistant, Diversification, Good } \\
\text { business }\end{array}$ \\
\hline Copoazu & & $\begin{array}{l}\text { Theobroma } \\
\text { grandiflorum }\end{array}$ & 6 & $\begin{array}{l}\text { Forest, Brazilian border } \\
\text { (Iñapari), Seed exchange }\end{array}$ & $\begin{array}{l}\text { High nutritional content, } \\
\text { Diversification, Pest resistant, Good } \\
\text { business }\end{array}$ \\
\hline Cacauillo & & $\begin{array}{l}\text { Theobroma } \\
\text { speciosa }\end{array}$ & 1 & Forest & Good business \\
\hline
\end{tabular}

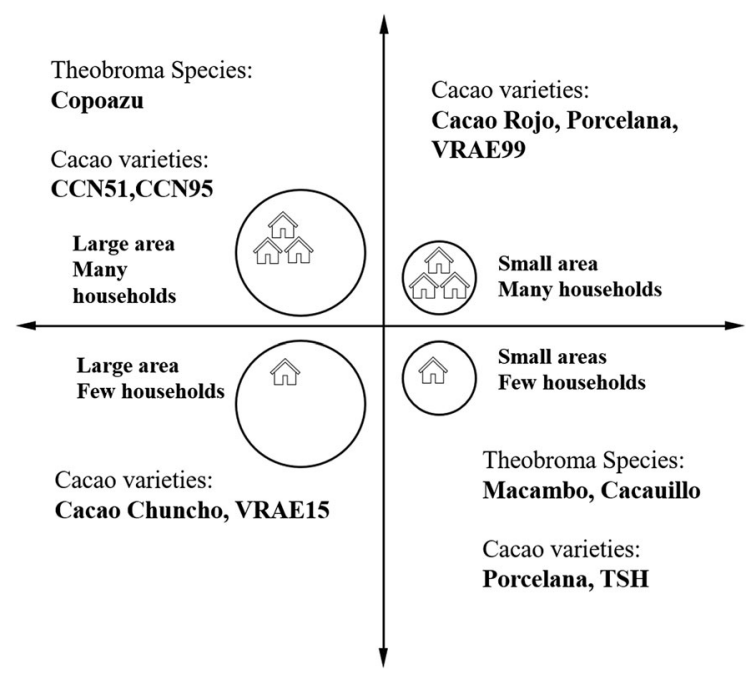

Fig. 2 Results of the 4SqA representing different Theobroma species (TS) and cacao varieties (CB) on two scales - cultivated area and number of households cultivating the species or variety

more in the future (Q13). In addition, they tended to associate it with an increased social and cultural value
(Q10) and better resistance to pests (Q7). Q6 (full sun) was pointing in the opposite direction to the copoazu and macambo cluster, suggesting a cultivation of those species in the shade. The second cluster is composed of VRAE99, CCN95 and cacao chuncho. All three were associated to low yields (Q3) and a high demand on the market $(\mathrm{Q} 1)$.

\section{Discussion}

In this study, we identified four Theobroma species (TS) and 9 cacao varieties (CV) managed by smallholder farmers in the Peruvian Amazon. We identified how farmers provided themselves with seeds and seedlings, managed the species and varieties and explored their motivations for cultivating each TS and CV. 


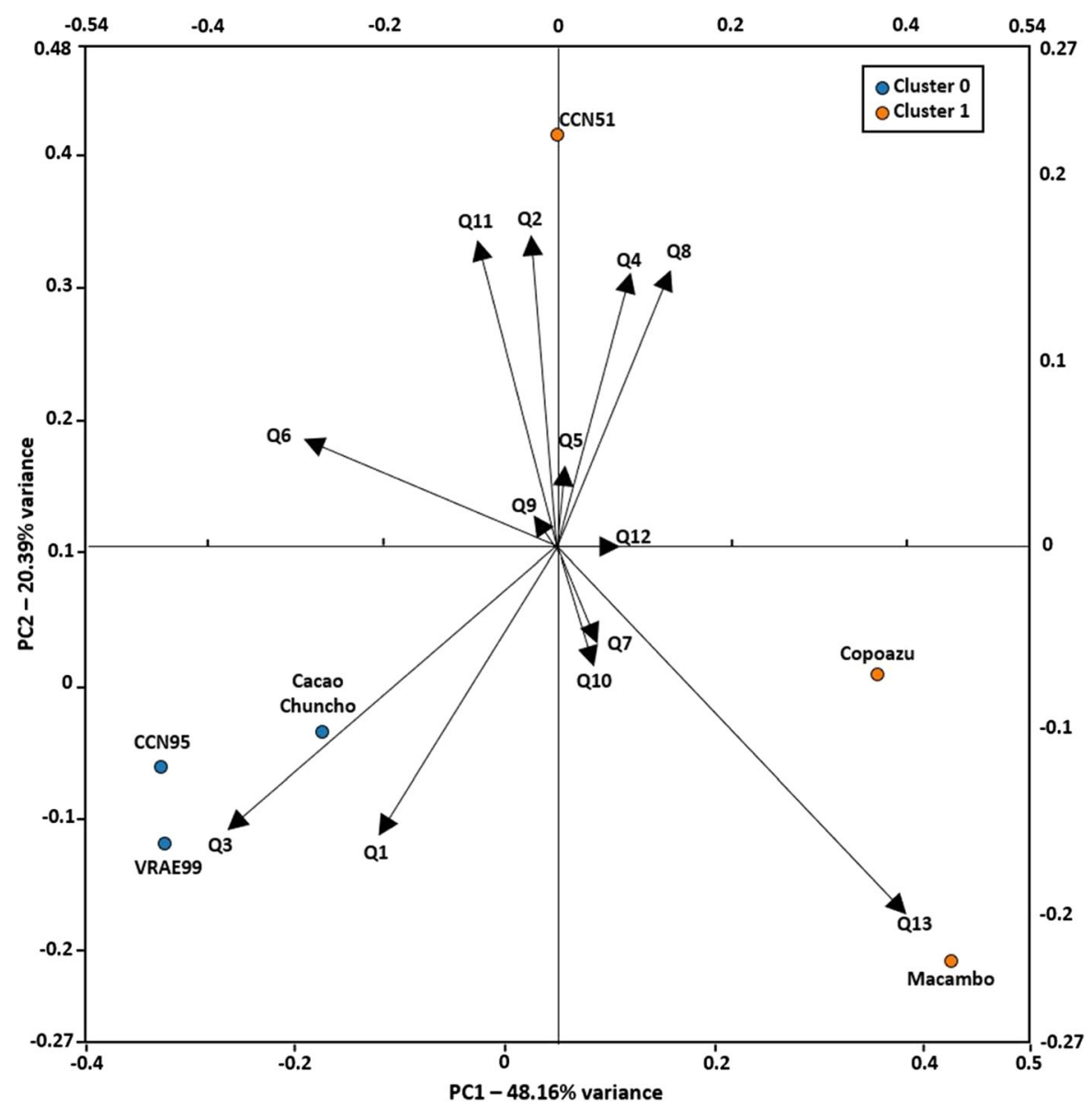

Fig. 3 Results of the PCA

\section{Theobroma diversity}

$\mathrm{CV}$ are usually divided in three generic groups: criollo, usually valued for its fine aroma; forastero, originally from the Amazon basin, making up most of the global production because of its higher yield; and trinitario, a hybrid derivative between criollo and forastero (Whitkus et al. 1998). Some varieties are hybrids between these different groups. In our study, most mentioned species were known to regional agronomists and mentioned in the Cacao Management Plan of Madre de Dios (MINAGRI 2019a, b). This was not the case for the variety "VRAE95", mentioned by two farmers, which led us to conclude to a mistake related to the confusing acronyms and considered it VRAE99 instead. Cacao chuncho, the variety cultivated by most farmers, refers to the native cacao that grows naturally in the region of Madre de Dios and it is valued for its flavor and robustness. It is associated to the forastero genetic group (MINAGRI 2019a, b). The $\mathrm{CCN}$ varieties refer to international hybrids that were crossed in Ecuador to produce high yields, but which produce lower quality chocolate. VRAE varieties are forastero clones originating from the Valle del Río Apurímac-Ene in the Peruvian department of Ayacucho (Motamayor et al. 2002). TSH (Trinidad Select Hybrids) cacao is a hybrid originally bread in Trinidad and Tobago. Porcelana, also called cacao blanco, is a criollo variety originating from the department of Piura in Peru, valued for its fine aroma (Quiñones et al. 2018). Cacao Rojo probably refers to an unidentified hybrid. The benefits mentioned by the farmers for each CV (e.g. yield, pest tolerance, taste) where coherent with the information available about the varieties in the literature. This suggests they were well informed on the topic and that our results are based on expert 
knowledge. The same is true for copoazu, macambo, and cacauillo, the TS mentioned by farmers.

\section{Theobroma seeds and seedlings}

Seed sources, supply chains and support systems by the government and NGOs were already analyzed in Peru (Bordie et al. 1997). It was shown that more than $65 \%$ of the fruit tree species came from smallholder systems (Bordie et al. 1997). Access to seeds and seedlings can be facilitated during events such as the seed fair, during which our study took place. This fair in particular was self-organized and informal, without governmental support. Yet, such events are valuable tools to establish social networks, which are important drivers for genetic resource and knowledge exchange (Almekinders et al. 2016). This is particularly true for regions such as Madre de Dios, in which farmers live geographically dispersed.

Our results showed that the access to seeds and seedlings varied between three groups of Theobromas: first the international clones, i.e. $\mathrm{CCN}$ and VRAE varieties, that were often accessed through technicians (meaning that they were donated by public institution projects) and by the local government (GOREMAD); second the native and criollo varieties i.e. cacao chuncho and porcelana, that were mainly accessed through local NGOs and other farmers; and finally the TS, which were only accessed directly from the forest or through exchange with other farmers. Overall, the most popular Theobromas were accessed through a multitude of sources, with exchange between farmers (neighbors, cooperatives, seed-exchange events) being an important source. This highlights the importance of seed and seedling access to the development of diverse farming systems.

Increasing the diversity of the local farming systems is important for a variety of reasons. Clough et al. (2009) describe the "cacao boom and bust", in which the increase in cacao production leads to shade removal and biodiversity loss and eventually to land depletion. This scenario could be avoided by increasing the diversity of Theobromas on smallholders' farms. The promotion of diverse TS and CV with high market potential-such as macambo, copoazu and cacao chuncho, would give farmers access to global and local markets, while maintaining biodiversity and fertile soils, thereby avoiding the cacao "boom and bust" effect. Nevertheless, our results suggest that the local government and farmer outreach programs focus on the donation of few $\mathrm{CV}$, mainly known for their productivity, e.g. CCN51, instead of incentivizing the cultivation of a variety of Theobromas. This loss of agricultural variety, following the introduction of higher-yielding varieties, was already documented in Peru for the case of potatoes cultivation (Brush et al. 1992). In this case, local varieties such as cacao chuncho, with traditional value, could suffer from competition with newly introduced clonal varieties. Indeed, cacao chuncho was the most adopted Theobroma by the farmers we interviewed, but it was perceived as cultivated by few households. A local NGO (Caritas) had provided some farmers with seedlings, but government-led donation campaigns were not promoting the native variety.

\section{Theobroma decision-making and management}

Our results suggest that cacao farmers in Madre de Dios mainly choose CV and TS that improve their position on the market. Specifically, they mainly choose varieties that have a high demand on the market (e.g. CCN95, VRAE99, cacao chuncho) or that they believe to be part of a growing market (e.g. copoazu, macambo). Surprisingly, some of the most cultivated varieties were associated to low yields. This is the case for cacao chuncho, that was also valued for its taste and traditionality. This is consistent with the species being a high quality but low-yielding cultivar. This is also in line with findings from another study using the same methodology $(4 \mathrm{SqA})$, in which farmers not only chose highly producing banana cultivars, but also varieties with contrasting favorable characteristics, including taste (Kilwinger et al. 2019). The two more industrial $\mathrm{CCN}$ cacao varieties were perceived very differently: CCN51 was valued for its high yield and drought resistance, but associated to a low demand, and possibly therefore valued for selfconsumption instead. CCN95 was associated to low yields (despite one farmer mentioning high yields as a driver for increased cultivation in the future) and to a high demand on the market. It was also the one out of the two adopted by most farmers. Yet, it is notable that the more industrial varieties, incentivized by public institutions, were much less often mentioned as desirable for future investment than TS i.e. macambo and copoazu, which were valued for their resistance to pests, high market potential and cultural value. 
With the results from the 4SqA (Fig. 2), we were able to highlight TS and CV facing a possible risk of local erosion (Grum et al. 2003): two TS, macambo and cacauillo; and two CV, TSH and Porcelana. In the case of macambo, this is consistent with the species being a slower maturing fruit tree which needs over 25 years to thrive (Coomes et al. 2000) and that is successful in local communities mainly for domestic consumption and sales on the local market (López et al. 2017). The species sustains the farming households with regional market access and is part of more diversified agroforestry system, which contrasts with the CV CCN95, which has an internationally established market, and species like copoazu, believed to have a high market potential. Nevertheless, the mention of macambo as a desirable species for the future suggests a limited risk of local erosion, in comparison to cacauillo. Regarding TSH cacao, a variety accessed by farmers through government-led donation campaigns, the perception that it is cultivated by few farmers on small areas could mean that it is in competition with more promoted clones such as $\mathrm{CCN}$ varieties. In the case of porcelana cacao, the highquality variety that farmers accessed through informal exchange, its low adoption could suggest an insufficient local production, keeping potential buyers away and thereby reinforcing the loop of low adoption.

We learned from farmer's motivations that they used different management techniques depending on which Theobroma they cultivate. For example, we highlighted that TS such as macambo and copoazu are not planted in full sunlight. In parallel, farmers mentioned in the case of macambo and copoazu, the diversification of the farming system as a motivation for future cultivation. These results suggest that agroforestry systems that include TS are multi-strata and more diverse than systems based on cacao production only. Yet, this study is one of the first to look at Theobroma-based agroforestry systems, and many more questions remain for future research about the potential of adding other Theobroma species to cacao-based agroforestry systems.

\section{Conclusions}

In a booming context of cultivar transition, it is easy for public institutions to neglect the long-term impacts of their investments in a single crop. In the case of
Madre de Dios, in the Peruvian Amazon, the "cacao boom" is already reaching hundreds of smallholder farmers who are incentivized to shift their production towards cacao-based systems. This study highlights the role of different TS and CV in the management of the agroecosystem, and the risks associated to the promotion of single cacao varieties. Farmers are currently incentivized by public programs to plant more high-yielding cacao varieties, such as CCN51, that they perceive as having a low demand on the market and that they are less motivated to plant more of in the future. In parallel, farmers intend to invest in species such as macambo, which are not promoted by local farmer outreach programs, despite their potential to diversify the farming system. Therefore, we recommend the extension of public cacao-donation campaigns to neglected and underutilized TS such as macambo and cacauillo, and native CV such as cacao chuncho and porcelana. These varieties have socioeconomic and environmental benefits to offer, in addition to being well suited for multi-strata agroforestry systems and perceived as desirable to farmers. This study also highlights the importance of seed and seedling exchange networks for the farmers management of a diversity of Theobroma species and varieties. Tailored seed supply chains for smallholder farmers have the potential to make the local farming systems more diverse, more resilient and less vulnerable to global cacao prices. Finally, we stress the importance of research focusing on farmers preferences and decision-making, in particular in such rapidly changing contexts, where local agrobiodiversity in put in jeopardy.

Acknowledgements This research did not receive any specific grant from funding agencies in the public, commercial, or not-for-profit sectors. We are grateful to all farmers who participated in this study and to the NGO Asociación Agricultura Ecologica for organizing the seedexchange fair in Puerto Maldonado. We also thank Robin Van Loon from the NGO Camino Verde, for his precious suggestions and expert advices.

Open Access This article is licensed under a Creative Commons Attribution 4.0 International License, which permits use, sharing, adaptation, distribution and reproduction in any medium or format, as long as you give appropriate credit to the original author(s) and the source, provide a link to the Creative Commons licence, and indicate if changes were made. The images or other third party material in this article are included in the article's Creative Commons licence, unless indicated otherwise in a credit line to the material. If material is not 
included in the article's Creative Commons licence and your intended use is not permitted by statutory regulation or exceeds the permitted use, you will need to obtain permission directly from the copyright holder. To view a copy of this licence, visit http://creativecommons.org/licenses/by/4.0/.

\section{References}

Almekinders CJM, Ronner E, van Heerwaarden J (2016) Tracing seed diffusion from introduced legume seeds through N2Africa demonstration trials and seed-input packages (No. 92). N2Africa

Andrieu N, Howland F, Alba IA, Le Coq JF, Osorio AM, Martinez-Baron D, Chia E (2019) Co-designing climatesmart farming systems with local stakeholders: a methodological framework for achieving large-scale change. Front Sustain Food Syst 3:37

Andreotti F, Mao Z, Jagoret P, Speelman EN, Gary C, Saj S (2018) Exploring management strategies to enhance the provision of ecosystem services in complex smallholder agroforestry systems. Ecol Ind 94:257-265. https://doi.org/ 10.1016/j.ecolind.2018.06.048

Andreotti F, Speelman EN, Van den Meersche K, Allinne C (2020) Combining participatory games and backcasting to support collective scenario evaluation: an action research approach for sustainable agroforestry landscape management. Sustain Sci 15(5):1383-1399

Brodie AW, Labarta-Chávarri RA, Weber JC (1997) Tree germplasm management and use on-farm in the Peruvian Amazon: a case study from the Ucayali region, Peru. ODI London and ICRAF Nairobi, London

Brush SB, Taylor JE, Bellon MR (1992) Technology adoption and biological diversity in Andean potato agriculture. J Dev Econ 39(2):365-387

Caballero Espejo J, Messinger M, Román-Dañobeytia $\mathrm{F}$, Ascorra C, Fernandez L, Silman M (2018) Deforestation and forest degradation due to gold mining in the Peruvian Amazon: a 34-year perspective. Remote Sens 10(12):1903

Cerda R, Allinne C, Gary C, Tixier P, Harvey CA, Krolczyk L, Mathiot C, Clément E, Aubertot JN, Avelino J (2017) Effects of shade, altitude and management on multiple ecosystem services in coffee agroecosystems. Eur J Agron 82:308-319

Clough Y, Faust H, Tscharntke T (2009) Cacao boom and bust: sustainability of agroforests and opportunities for biodiversity conservation. Conserv Lett 2:197-205. https://doi. org/10.1111/j.1755-263x.2009.00072.x

Coomes OT, Grimard F, Burt GJ (2000) Tropical forests and shifting cultivation: secondary forest fallow dynamics among traditional farmers of the Peruvian Amazon. Ecol Econ 32(1):109-124

Deheuvels O, Avelino J, Somarriba E, Malezieux E (2012) Vegetation structure and productivity in cocoa-based agroforestry systems in Talamanca, Costa Rica. Agric Ecosyst Environ 149:181-188

Ellison D, Morris EC, Locatelli B, Sheil D, Cohen J, Murdiyarso D, Gutierrez V, Van Noordwijk M, Creed IF, Pokorny J, Gaveau D, Spracklen DV, Tobella AB, Ilstedt U, Teuling
AJ, Gebrehiwot SJ, Sands D, Muys B, Verbist B, Springgay E, Sugandi Y, Caroline AS (2017) Trees, forests and water: cool insights for a hot world. Glob Environ Change 43:51-61

Finer M, Mamani N (2018a) Minería Aurífera alcanza Máximo Histórico de Deforestación en la Amazonía Sur Peruana. MAAP:96

Finer M, Mamani N (2018b) Hotspots de Deforestación del 2018 en la Amazonía Peruana. MAAP: 98

Grum, M., Gyasi, E. A., Osei, C., \& Kranjac-Berisavljevic, G. (2003). Evaluation of best practices for landrace conservation: farmer evaluation

Herrero-Jáuregui C, Arnaiz-Schmitz C, Herrera L, Smart SM, Montes C, Pineda FD, Schmitz MF (2019) Aligning landscape structure with ecosystem services along an urbanrural gradient. Trade-offs and transitions towards cultural services. Landsc Ecol 34(7):1525-1545

INEI (2018) Madre de Dios, Compendio Estadístico 2018

MINAGRI (2019a) Madre de Dios: Minagri invierte S/ 10 millones en Proyectos de Reconversión Productiva. Nota de Prensa. https://www.gob.pe/institucion/minagri/ noticias/29160-madre-de-dios-minagri-invierte-s-10millones-en-proyectos-de-reconversion-productiva. Retrieved 19 Dec 2019

MINAGRI (2019b) Plan de Manejo de Cacao en la Región de Madre de Dios. PROGRAMA DE RECONVERSIÓN PRODUCTIVA-2019

Lever J, Krzywinski M, Altman N (2017) Points of significance: principal component analysis. Nat Methods 14(7):641-642

Kilwinger FBM, Rietveld AM, Groot JCJ, Almekinders CJM (2019) Culturally embedded practices of managing banana diversity and planting material in central Uganda. J Crop Improv. https://doi.org/10.1080/15427528.2019.1610822

López RPJ, Zamora Chávez MM (2017) Plan de negocio para la elaboración y comercialización de helados de Macambo, año 2017. http://repositorio.ucp.edu.pe/handle/UCP/241

Mersmann O (2014) mco: Multiple Criteria Optimization algorithms and related functions. $\mathrm{R}$ package version 1.015.1. https://CRAN.R-project.org/package $=$ mco

Mortimer R, Saj S, David C (2017) Supporting and regulating ecosystem services in cocoa agroforestry systems. Agrofor Syst 92:1-19

Motamayor JC, Risterucci AM, Lopez PA, Ortiz CF, Moreno A, Lanaud C (2002) Cacao domestication I: the origin of the cacao cultivated by the Mayas. Heredity 89(5):380-386

Nelson V, Phillips D (2018) Sector, landscape or rural transformations? Exploring the limits and potential of agricultural sustainability initiatives through a cocoa case study. Bus Strateg Environ 27(2):252-262

Peña Valdeiglesias J (2018) Sistematización de Experiencias del proyecto "Fortaleciendo Medios de Vida ante el Cambio Climático en Madre de Dios, Amazonia Peruana, 2016-2018", CARITAS

Quiñones M, Espinoza E, Yovera F, Cuchilla Y, Castro D (2018) Identification, georeferencing and morphological characteristics of upper trees of Theobroma cacao L. 1753 cultivar White Cocoa of Piura, Peru. The Biologist (Lima) 16(1):105-117

R Core Team (2013) R: A language and environment for statistical computing 
Rafael Condo, President of FADEMAD, Personal Communication, September 20, 2019

Revelle W (2017) Using the psych package to generate and test structural models

Rojas R (2014) Social movement organisations and the unsustainability of sustainable initiatives. Manuscript, not published

Saj S, Durot C, Mvondo Sakouma K, Tayo Gamo K, AvanaTientcheu ML (2017) Contribution of associated trees to long-term species conservation, carbon storage and sustainability: a functional analysis of tree communities in cacao plantations of Central Cameroon. Int J Agric Sustain 15(3):282-302

Sauvadet M, Meersche KVD, Allinne C, Gay F, Filho EDMV, Chauvat M, Becquer T, Tixier P, Harmand J-M (2019) Shade trees have higher impact on soil nutrient availability and food web in organic than conventional coffee agroforestry. Sci Total Environ 649:1065-1074 van Noordwijk M, Coe RD, Sinclair FL (2016) Central hypotheses for the third agroforestry paradigm within a common definition. ICRAF working paper

van Noordwijk M, Speelman E, Hofstede GJ, Farida A, Abdurrahim AY, Miccolis A, Hakim AL, Wamucii CN, Lagneaux E, Andreotti F, Kimbowa G (2020) Sustainable agroforestry landscape management: changing the game. Land 9(8):243

Whitkus R, De la Cruz M, Mota-Bravo L, Gómez-Pompa A (1998) Genetic diversity and relationships of cacao (Theobroma cacao L.) in southern Mexico. Theor Appl Genet 96(5):621-627

Publisher's Note Springer Nature remains neutral with regard to jurisdictional claims in published maps and institutional affiliations. 